\title{
What Is Craft?-An Empirical Analysis of Consumer Preferences for Craft Beer in Italy
}

\author{
Christian Garavaglia',2, Mauro Mussini ${ }^{1}$ \\ ${ }^{1}$ Department of Economics Management and Statistics (DEMS), University of Milano-Bicocca, Milan, Italy \\ ${ }^{2}$ Invernizzi Center for Research on Innovation, Organization, Strategy and Entrepreneurship (ICRIOS), Bocconi University, \\ Milan, Italy \\ Email: christian.garavaglia@unimib.it,mauro.mussini1@unimib.it
}

How to cite this paper: Garavaglia, C., \& Mussini, M. (2020). What Is Craft?-An Empirical Analysis of Consumer Preferences for Craft Beer in Italy. Modern Economy, 11, 1195-1208.

https://doi.org/10.4236/me.2020.116086

Received: May 11, 2020

Accepted: June 25, 2020

Published: June 28, 2020

Copyright (C) 2020 by author(s) and Scientific Research Publishing Inc. This work is licensed under the Creative Commons Attribution International License (CC BY 4.0).

http://creativecommons.org/licenses/by/4.0/

\begin{abstract}
This paper discusses the term "craft" and its meaning from the consumer's perspective. Consumers assign value to craft products for their uniqueness, customization, originality, and personality. Craft products are usually sold at higher prices than non-craft products. Therefore, we need to understand what consumers expect in a craft product. We collect original data and present an empirical investigation using conjoint analysis. We focus on the case of craft beer in Italy. Based on our results, consumers believe that the ownership, firm size, and production process are crucial attributes that define craft beer. In particular, we show that consumers believe that craft beer is produced by an independent (family-owned) firm in a small-scale plant and is non-pasteurized.
\end{abstract}

\section{Keywords}

Craft, Consumer Preferences, Conjoint Analysis, Beer

\section{Introduction}

The contribution of small craft (artisan) firms to the local economy has been extensively discussed in the economic literature (Brusco \& Sabel, 1981; European Network for SME Research, 1997; Sennett, 2008; Crawford; 2009; Micelli, 2011; Abisuga-Oyekunle \& Fillis, 2017). Craft products are often associated to something unique and original embodying the craftsmen's personality. These products have proliferated in the midst of mass production and consumption, and they represent an ideology-not just something merely designed for consumption (Jakob, 2013). The belief that craft products express something different from standardized commodities and guarantee unique traits and quality induces 
consumers to pay premium prices for them.

The purpose of this paper is to investigate the meaning of the term "craft". Usually, this term is defined from the producers' perspective. However, in this study, we analyze the meaning of the term from the consumers' perspective. Thus, the research question of this paper is: what do consumers perceive in craft? This is an important issue. If consumers perceive value in craft products, and therefore are willing to pay more for them, then they should know for what characteristics of the products they are willing to pay; that is, they should know what characteristics have craft and what does not. This is an underexplored topic.

The research context of this study is the Italian beer market. The advent of craft breweries revolutionized the beer market in Italy (Garavaglia \& Swinnen, 2018a). Recently, the discussion about what constitutes craft beer has been vibrant in this market. The growth of successful craft breweries led to significant increases in their size, thus stimulating debates on a size limit for craft breweries (if any). In addition, the recent acquisition of craft breweries by multinationals raised the question of independence: are these acquired breweries still craft? These questions illustrate the need to explain the concept of craft in the beer market. A conjoint analysis shows that the independent ownership and smallscale of production are the main criteria contributing to what consumers define as craft in beer brewing. Production process (non-pasteurization) also plays an important role, but place of production is not significant.

The paper is structured as follows: Section 2 discusses the concept of craft and craftwork, Section 3 presents the case of craft beer, Section 4 specifies the methodology, Section 5 describes the data used, Section 6 discusses the results of the analysis, and, finally, Section 7 concludes the paper.

\section{Craft and the Rediscovery of Craftwork}

The Oxford Dictionary defines craft as an activity involving the skill to create goods by hand. The term craft represents production activities for the manufacture of goods using manual labor, that is, without the use of machines, or with the marginal use of machines, and employing a limited number of workers in small-scale production.

Traditionally, craft producers are family-based units selling their products locally (Ratten \& Tajeddini, 2017; Marques et al., 2019). The thought of anything related to craft evokes the idea of uniqueness, originality, and personality. Craftsman behavior is characterized by precise routines beyond mere production activities; it includes the choice of raw materials and techniques, processing procedure, and packaging. Numerous studies report that craftsmen are not stimulated by financial and growth motives, but have personal satisfaction and lifestyle goals (Hornaday, 1990; Fillis, 2002; Greenhalgh, 2003; Poettschacher, 2005; Chatterjee et al., 2017). Everything is done with a focus on the consumer. The common feeling is that craft indicates quality. Given the uniqueness, customiza- 
tion, originality, and personality of craft products, consumers are willing to assign value to craft products and pay premium prices for them.

The recent rediscovery of craftwork in many industries has been an opportunity to react against industrialization and mass production (Jakob, 2013). Craft is supposed to give meaning to work and the pride of personal achievement in the process of work (Inkson, 1987). The importance and socio-cultural meaning of craftwork have been clearly emphasized by Sennett (2008), Johnson (2009), Crawford (2009), and Micelli (2011). They investigate the rediscovery of craft production and its importance and competitiveness in the global economy. While industrial production has evolved toward commoditization of goods, a craftsman is continuously pursuing the customers' increasing need for exclusive products and directly engages in the creation of demand.

The notion of craft has been used to interpret a new consumer demand for the products of an identified person who applies his craft knowledge to produce goods of quality and authenticity (Campbell, 2005). Pietrykowski (2004) refers to a network of producer-consumer relations that allow small-scale producers to maintain their traditional production methods and products related to food consumption and agriculture. This view is embodied in the Slow Food Movement, which, since its foundation in 1987 in Italy, has gained success all over the world. As for the Movement, Sassatelli \& Davolio (2010) emphasize the role of both consumers, the key element of change, and cultural entrepreneurs, the promoters of craft products. Notwithstanding the acknowledged role of consumers, the issue of how they define craft products has not received much attention in the literature.

\section{What Is Craft Beer?}

After a century of the consolidation of breweries, domination of a few global multinationals, and homogenization of beer, a few small craft breweries entered the market, to transform the beer scene. This occurred across the global (Garavaglia \& Swinnen, 2018a, 2020).

While the consolidation of breweries generally implied loss of variety, new craft breweries entering the market offered highly differentiated beers. Most craft breweries gradually enlarged their beer portfolios, introducing new beers characterized by different styles every year. The totality of the craft beer available in the market reflected Clemons et al.'s (2006) definition of hyper-differentiation as the increased importance of being truly different. Firms use hyper-differentiation to reduce the importance of price as the principal determinant of customer choice from multiple goods and services. Clemons et al. (2006) claim that in the United States, hyper-differentiation increases the diversity in craft beer and ultimately the prices of beer as well as consumer satisfaction. Consumers who value craft beer positively are willing to pay higher prices (Garavaglia \& Swinnen, 2018b; Elzinga et al., 2018; Fertö et al., 2018). Therefore, firms need to know the factors that consumers identify with craft beer. 
The definition of craft beer has been usually presented from the producer's perspective. Craft brewery, microbrewery, local brewery, and artisanal brewery are the most commonly used terms (we use the terms craft brewery and craft beer). Generally, these terms relate to the production of beer carried out during the last few decades, in contrast to mass production of beer by the old large-scale incumbent breweries. Several attempts have been made to define craft brewing in various countries (Garavaglia \& Swinnen, 2018a). However, given the diverse approaches of countries and their different historical traditions in beer brewing, and considering the various legislations in the beer market, we do not have an accepted general definition for the terms "craft beer" and "craft brewery." In what follows, we highlight the criteria most used in the definitions of craft brewery: ownership, size, age, production process, and origin. Each of them has limitations.

\subsection{Ownership}

Craft breweries are assumed to be independent. As the number of breweries declined, a few very large industrial breweries started to dominate the market, while smaller ones exited the market or were acquired. The smaller breweries that were acquired could retain their official name, but were under the control of the larger producers that acquired them, with no independence to manage the brewing of beers. The interpretation of this criterion in accordance with the craft feeling is that the breweries need to be independent of the incumbent mass producer and be characterized as being free from third producer control. The limit of this criterion is that if a craft brewery is acquired by a multinational, it loses its independence but continues to produce the same beer [Garavaglia \& Swinnen (2018b) named these as ex-craft breweries].

\subsection{Size}

Craft breweries have been defined in terms of scale of production. However, their production scale is directly related to the size of the country where they operate. For example, the American Brewers Association considers a beer brewery to be a craft brewery when its annual production is under 6 million barrels [i.e., 7,038,000 hectoliters (hl)]; this upper limit is 200,000 hl (i.e., 170,502 barrels) in Italy and 50,000 hl (i.e., 42,625 barrels) in Spain. Note that if the US scale limit were considered universally, then all the breweries in Italy, such as Heineken Italia and Carlsberg Italia, would be craft breweries. Furthermore, note that the growth rates of some craft breweries are such that they are not relatively small anymore.

\subsection{Firm Age}

Craft brewing is a relatively recent phenomenon. The first craft beer producers in most countries started brewing in the 1980s and 1990s (Garavaglia \& Swinnen, 2018a). However, traditional artisanal beer production has been going on in 
Europe for centuries, particularly in countries with a long history in beer brewing, such Germany, Belgium, and the United Kingdom. Therefore, the age of the producer might be a misleading measure because an historical producer could have been brewing beer by the craft beer philosophy.

\subsection{Production Process}

The concept of craft beer in some countries is related to the production process or use of ingredients. For example, craft beer is not subject to pasteurization or even micro-filtration in Italy. Pasteurization is a heat treatment process during the packaging phase to kill pathogens and keep the beer sterile. Micro-filtration removes yeast particles in the fermenting mixture. These treatments increase the beer shelf life and guarantee product consistency. However, these processes can flatten some organoleptic fragrance characteristics of beer and reduce their flavor and aroma, thus contributing to loss of the distinctive beer taste. This criterion might be relevant in Italy, but it is not considered in other countries. Note also that multinationals have recently started to produce "craft style" beer, such as unfiltered beer.

\subsection{Local}

In their definition of craft beer, the American Brewers Association specifies that craft brewers tend to be fully involved in their community. Craft breweries are surrounded by local activities related to beer festivals, local promotions, and linkages with local agricultural activities (Schnell \& Reese, 2003; Schnell, 2013; Garavaglia, 2020; American Brewers Association). Craft beer, as well as various other craft products, is usually sold within the region of production. Consumers usually choose a local beer in pubs assuming that craft beer is produced nearby. Garavaglia (2020) identifies at least three types of relationship between craft beer and space: giving a dialect the name of a beer, giving geographical places the name of a firm/brand, and using local ingredients in beer production. All craft breweries started as small and locally oriented plants. This criterion presents obvious limitations: above all, consumers living near the production plant of old large-scale incumbent breweries do not consider their product craft beer.

This study focuses on the case of craft beer in Italy. In 2016, the Italian Parliament ${ }^{1}$ defined craft breweries as small independent producers whose beer does not undergo pasteurization and micro-filtration during the production process. An independent brewery means a brewery that is legally, economically, and physically independent of any other brewery; it does not operate under license, and has an annual production not exceeding 200,000 hl. Then, in 2019, the Italian Parliament ${ }^{2}$ approved an excise reduction for craft breweries. They

${ }^{1}$ Collegato Agricoltura, DDL (Disegno Di Legge) n. 1328-B, which modifies article 2 of the Law n. 1354 (16 Agosto 1962). Available at: http://www.senato.it/japp/bgt/showdoc/17/DDLPRES/965677/index.html. ${ }^{2}$ https://www.gazzettaufficiale.it/eli/gu/2019/06/14/138/sg/pdf. 
identified craft breweries as firms that produce not more than 10,000 hl of beer annually, are legally and economically independent of any other brewery, produce their own beer without receiving beer from other firms, use plants physically distinct from any other brewery, and do not operate under license. In conclusion, the Italian legislation identifies a craft brewery by its size, ownership, and production process.

\section{Methodology}

This study adopts the conjoint analysis methodology, which has been widely used to investigate the consumer choice behavior in business studies for many years (Green \& Srinivasan, 1978, 1990; Cattin \& Wittink, 1982, Green \& Krieger, 1991). This method is interesting in that it can be applied where changes are multi-dimensional and the links between them are important. Moreover, respondents are not asked to explicitly determine their preferences. The results obtained through conjoint analysis are considered more realistic than those sourced through methods where consumers are directly asked for their preferences, such as contingent valuation (Henson, 1996; Walley et al., 1999; Krystallis \& Chryssohoidis, 2005).

We can refer to a product as a set of characteristics (variables) defining the product, in a Lancasterian spirit (Lancaster, 1966, 1971), where consumers derive utility from the properties of each single characteristic of the product. Following Green \& Srinivasan (1978), we show that the variables describing a product (or service) are its attributes, and the values of each attribute are the levels of that attribute. The combination of the attribute levels in a certain manner defines a product profile called stimulus. We can obtain a set of alternative stimuli by combining the attribute levels in different ways. Once a set of alternative stimuli has been generated, a conjoint survey asks each respondent to rate (or rank) the stimuli to reflect the respondent's preference. We use the conjoint ranking response format to obtain additional information on the respondent's preferential judgment for each stimulus in terms of utility. Using a part-worth utility function to model the respondent's preference structure, conjoint analysis separates the utility of a stimulus into part-worth utilities, that is, utility scores of the attribute levels describing the stimulus in a conjoint survey. A rating scale is used to measure the preferential expressions (Green \& Srinivasan, 1978). We exploit the information in the rating conjoint format by regressing the individual responses on a linear function of all the attribute levels describing the products in question. Given that conjoint data are collected on a metric scale, our choice of ordinary least squares (OLS) estimation is appropriate. We consider a product to have $P$ alternative stimuli when its attribute levels are combined in different ways. In this case, the part-worth function model (Green \& Srinivasan, 1978) is

$$
U_{p}=\beta_{0}+\sum_{k=1}^{K} \sum_{j=1}^{J_{k}} \beta_{k j} x_{p k j}+\varepsilon_{p}
$$

where 
$U_{p}$ is the utility for stimulus $p$, with $p=1, \cdots, P$,

$\beta_{0}$ is the constant;

$\beta_{k j}$ is the part-worth utility for the $j$-th level of the $k$-th attribute, with $j=1, \ldots$, $J_{k}$ and $k=1, \cdots, K$;

$x_{p k j}$ is a dummy variable equal to 1 when stimulus $p$ includes the $j$-th level of the $k$-th attribute, and 0 otherwise; and

$\varepsilon_{p}$ is the error term in the model.

We use the part-worth model in Equation (1) to examine what the respondents feel about craft beer in the next section. The relative importance of each attribute in determining respondent's preferences can be measured by using the following formula (Mariani et al., 2019):

$$
I_{k}=\frac{\max \left(\beta_{k j}\right)-\min \left(\beta_{k j}\right)}{\sum_{k=1}^{K}\left[\max \left(\beta_{k j}\right)-\min \left(\beta_{k j}\right)\right]}
$$

where the relative importance for attribute $k$ is obtained by dividing the range of the part-worth utilities for attribute $k$ by the sum of the ranges calculated for all attributes.

\section{Data}

This study uses original data obtained through a rating conjoint interview survey of 120 consumers. We conduct face-to-face interviews using an ad hoc questionnaire at a beer festival in Robecco sul Naviglio near Milan on July 5 and 6 , 2019. We selected all the respondents that live in the province of Milan.

For our preliminary investigation, we use a non-probability sampling method, that is a convenience sampling. We are aware that a convenience sample may be affected by a selection bias, as units can be included in the sample only if they are easily accessible (Sarstedt et al., 2018). However, we resorted to a convenience sampling owing to its cost-effectiveness to collect data. The sample size used in conjoint analysis is variable. Among others, Cattin \& Wittink (1982) report that sample sizes in commercial conjoint studies vary between 100 and 1000, with a usual range between 300 and 550, while Akaah \& Korgaonkar (1988) claim that the most common samples are smaller (less than 100).

We developed the questionnaire through a few questions to identify the consumer behavior in beer consumption and delineate the basic characteristics of craft beer, following previous studies, particularly Garavaglia \& Swinnen (2018a, 2018b). The questionnaire is in two parts. The first part includes a set of questions on the consumers' demographics and their purchase behavior of beer. This information is reported in Table 1.

The second part of the questionnaire investigates the respondents' perceptions of craft beer. In order to describe as accurately as possible the characteristics differentiating craft beer from non-craft beer, we select four attributes from our discussion in Section 3. We exclude the attribute "firm age" for two reasons. First, we limit the number of attributes to make the questionnaire easier for 
Table 1. Consumers' demographics and information.

\begin{tabular}{ccc}
\hline Gender & Male & $60 \%$ \\
& Female & $40 \%$ \\
Age group & $18-24$ & $10.8 \%$ \\
& $25-34$ & $57.5 \%$ \\
Frequency of beer consumption & $35-44$ & $16.6 \%$ \\
& $>44$ & $15.0 \%$ \\
Preference for craft or industrial beer & More than once a week & $56.7 \%$ \\
& Once a week & $26.7 \%$ \\
& Twice a month or less & $16.6 \%$ \\
& Craft & $47.5 \%$ \\
& Industrial & $24.2 \%$ \\
\hline
\end{tabular}

respondents to interpret. Second, "firm age" could mislead the respondents because it can be correlated to firm size. Each attribute has two possible characteristic levels:

- size: "6000 hl" or "1 million hl" per year; a smaller size more accurately represents a craft producer;

- ownership: "multinational" or "family-owned" firm; independence is a requisite of a craft brewery;

- production process: "pasteurized" or "non-pasteurized" beer; craft beer is required to be non-pasteurized in Italy;

- place of production: "local" or "non-local" production (given that in our data, all the respondents live in the province of Milan, we identify local production with the province of Milan and non-local production with the province of Cuneo; Cuneo is $250 \mathrm{~km}$ away from Milan); usually, consumers perceive a locally produced beer to have more craft traits.

Table 2 presents the attributes and related levels.

If a full factorial design is used, $2^{4}=16$ stimuli (profiles) can be constructed. However, since comparing and rating 16 alternative beer profiles may not be practical, we use a fractional factorial design, with a fraction of the profiles generated in full design. Several different types of fractional factorial designs can be used, but we choose the orthogonal main effects design since it is parsimonious and enables us to estimate the main attributes (Rao, 2014). Using this fractional factorial design, we select eight beer profiles for the respondents. These profiles are shown in Table 3. The respondents are asked to score eight profiles on a scale from 1 to 10 based on each profile's representativeness of the concept of craft, where 1 is the lowest score and 10 is the highest.

\section{Results}

We use conjoint analysis to estimate the utility consumers derive from each 
Table 2. Attributes and levels.

\begin{tabular}{cc}
\hline Attribute & Levels \\
\hline Size & 6000 hl per year \\
& 1 million hl per year \\
Ownership & Multinational \\
& Family-owned \\
Production process & Pasteurized beer \\
& Non-pasteurized beer \\
Place of production & Province of Milan (local) \\
& Province of Cuneo (non-local)
\end{tabular}

Table 3. Profiles.

\begin{tabular}{|c|c|c|c|c|}
\hline Profile & Place of production & Size & Ownership & Production process \\
\hline A & $\begin{array}{l}\text { Province of Cuneo } \\
\text { (non-local) }\end{array}$ & $\begin{array}{l}6000 \mathrm{hl} \\
\text { per year }\end{array}$ & Family-owned & Non-pasteurized beer \\
\hline B & $\begin{array}{l}\text { Province of Milan } \\
\text { (local) }\end{array}$ & $\begin{array}{l}1 \text { million } \mathrm{hl} \\
\text { per year }\end{array}$ & Family-owned & Non-pasteurized beer \\
\hline C & $\begin{array}{l}\text { Province of Milan } \\
\text { (local) }\end{array}$ & $\begin{array}{l}6000 \mathrm{hl} \\
\text { per year }\end{array}$ & Multinational & Non-pasteurized beer \\
\hline $\mathrm{D}$ & $\begin{array}{l}\text { Province of Cuneo } \\
\text { (non-local) }\end{array}$ & $\begin{array}{l}1 \text { million } \mathrm{hl} \\
\text { per year }\end{array}$ & Multinational & Non-pasteurized beer \\
\hline E & $\begin{array}{l}\text { Province of Milan } \\
\text { (local) }\end{array}$ & $\begin{array}{l}6000 \mathrm{hl} \\
\text { per year }\end{array}$ & Family-owned & Pasteurized beer \\
\hline F & $\begin{array}{l}\text { Province of Cuneo } \\
\text { (non-local) }\end{array}$ & $\begin{array}{l}1 \text { million } \mathrm{hl} \\
\text { per year }\end{array}$ & Family-owned & Pasteurized beer \\
\hline G & $\begin{array}{l}\text { Province of Cuneo } \\
\text { (non-local) }\end{array}$ & $\begin{array}{l}6000 \mathrm{hl} \\
\text { per year }\end{array}$ & Multinational & Pasteurized beer \\
\hline $\mathrm{H}$ & $\begin{array}{l}\text { Province of Milan } \\
\text { (local) }\end{array}$ & $\begin{array}{l}1 \text { million } \mathrm{hl} \\
\text { per year }\end{array}$ & Multinational & Pasteurized beer \\
\hline
\end{tabular}

attribute level. In Table 4 we report the part-worth utility estimates obtained using OLS regression with $\mathrm{R}$ software.

Table 4 shows that for each attribute, if the level increases or decreases the utility of a consumer; the coefficients values must be interpreted in relative terms (i.e., as more or less useful), and not in absolute terms (a negative value does not imply "disutility," but means that the utility is lower than that associated with a positive or less negative value.) From the results obtained, we can conclude that the respondents believe that smaller size better represents the notion of craft in beer production (with a partial utility of 0.753 ); family-ownership better identifies a craft brewery (with a partial utility of 1.111); non-pasteurized beer better represents the notion of craft beer (with a partial utility of 0.186 ); and, with regard to place of production, the province of Cuneo has a positive but small impact (0.049) whereas Milan has a negative impact. The result of the latter 
Table 4. Part-worth utility values.

\begin{tabular}{ccc}
\hline Attribute & Levels & Utility \\
\hline \multirow{2}{*}{ Size } & 6000 hl per year & $0.753^{* * *}$ \\
& 1 million hl per year & $-0.753^{* * *}$ \\
Ownership & Multinational & $-1.111^{* * *}$ \\
& Family-owned & $1.111^{\star * *}$ \\
Production process & Pasteurized beer & $-0.186^{* *}$ \\
& Non-pasteurized beer & $0.186^{* *}$ \\
Place of production & Province of Milan (local) & -0.049 \\
& Province of Cuneo (non-local) & 0.049 \\
\hline
\end{tabular}

${ }^{* * *}$ significant at 0.001 level; ${ }^{* *}$ significant at 0.01 level.

attribute is surprising because all the respondents live in the province of Milan: one would expect a closer location of the producer (i.e., Milan) to signal an image of more craft to consumers; however, this attribute is not statistically significant.

To sum up, Table 4 shows that consumers better identify craft beer with non-pasteurized beer produced in a small-scale family-owned (independent) firm.

Table 5 presents the relative importance of each attribute. The attribute most affecting the consumer perception of craft beer is the ownership (38.74\%). Production size is also important (29.40\%); production process determines the perception of craft for $18.96 \%$ consumers. Place of production is not significant.

Thus, from the consumer perspective, we can say that ownership is the most important criterion to identify the concept of craft beer. Consumers strongly value the independent familiar ownership. The production by the firm owned by an identified person/family better represents the notion of craft. We claim that this result confirms the idea that consumers believe that entrepreneurs transmit their personality into their products, thus providing an identity and craft sentiment. Firm size counts as well: small-scale production is associated with the idea of craft. This recalls the idea that small-scale production leads to more customization and exclusivity. Moreover, small-scale production ideally contrasts mass production, which embodies the typical industrial image of large factories producing standardized commodities. The production process used for making beer plays a key role too. For consumers, a production process with lower number of treatments, like non-pasteurization, better conforms to the idea of craft.

\section{Conclusion, Limitations, and Further Research}

This paper provides empirical evidence on what consumers believe to be craft beer. This is an interesting topic because small craft firms looking for higher prices for their products need to gain their consumers' willing to pay premium prices. Therefore, an analysis of what constitute the characteristics that consumers perceive as craft is crucial. 
Table 5. Attributes' importance values.

\begin{tabular}{cc}
\hline Attribute & Importance Levels \\
\hline Size & 29.40 \\
Ownership & 38.74 \\
Production process & 18.96 \\
Place of production & 12.89 \\
\hline
\end{tabular}

We conducted an empirical analysis in Italy through a questionnaire survey of 120 beer consumers. We carried out a conjoint analysis to study the characteristics that consumers believe to better conform to the concept of craft beer. From our findings, the ownership of the firm and scale of production represent the main criteria associated with the notion of craft beer. The production process is also an important factor for the identification of craft beer. Finally, place of production is not a significant criterion. In particular, our results show that consumers believe that craft beer is produced by an independent (family-owned) firm in a small-scale plant and is non-pasteurized.

We claim that this study contributes in the literature to provide evidence on the consumer perception of the notion of craft, which is an understudied issue. We also contribute to a vivid debate on what constitutes craft beer in the beer market. Finally, we believe that this paper could stimulate further research on these topics and extend the analysis to other countries and craft products. Another extension of this study could relate to the nonsignificance of the attribute place of production. We can explain this by the fact that Milan is identified with the most industrialized city in Italy, thus creating a misperception when thinking about craft in Milan. Also, it could be that the alternative "province of Cuneo (non-local)" that we presented in the description of the profiles is not too far away from the respondents' place of residence (that is province of Milan). If this is true, it could mean that the respondents do not perceive significant difference between the local and non-local levels. A possible future extension is defining the non-local level using a more distant place. This exercise could raise the interesting question of what constitutes the boundaries of the notion of local. This question we leave to a future study.

This work has some limitations. First, we collected data using non-probability sampling. Second, our analysis is specific to the Italian context. Thus, our results highlight the importance of non-pasteurization in the production process. As discussed in Section 3, this criterion is specifically employed in Italy, and it is not used in other countries. Therefore, our results could be strictly related to the common knowledge of Italian consumers. An interesting extension of this study could be to replicate the analysis using data collected from a foreign country where the definition of craft beer does not commonly require non-pasteurization.

\section{Acknowledgements}

The authors would like to thank Margherita Maccazzola for her support in data 
collection.

\section{Conflicts of Interest}

The authors declare no conflicts of interest regarding the publication of this paper.

\section{References}

Abisuga-Oyekunle, O. A., \& Fillis, I. R. (2017). The Role of Handicraft Micro-Enterprises as a Catalyst for Youth Employment. Creative Industries Journal, 10, 59-74. https://doi.org/10.1080/17510694.2016.1247628

Akaah, I., \& Korgaonkar, P. (1988). A Conjoint Investigation of the Relative Importance of Risk Relievers in Direct Marketing. Journal of Advertising Research, 28, 38-44.

American Brewers Association. Craft Brewer Definition. https://www.brewersassociation.org/statistics-and-data/craft-brewer-definition

Brusco, S., \& Sabel, C. (1981). Artisan Production and Economic Growth. In F. Wilkinson (Ed.), The Dynamics of Labour Market Segmentation (pp. 99-113). London: Academic Press.

Campbell, C. (2005). The Craft Consumer. Culture, Craft and Consumption in a Postmodern Society. Journal of Consumer Culture, 5, 23-42. https://doi.org/10.1177/1469540505049843

Cattin, P., \& Wittink, D. R. (1982). Commercial Use of Conjoint Analysis: A Survey. Journal of Marketing, 46, 44-53. https://doi.org/10.1177/002224298204600308

Chatterjee, S., Gupta, S. D., \& Upadhyay, P. (2017). Empowering Women and Stimulating Development at Bottom of Pyramid through Micro-Entrepreneurship. Management Decision, 56, 160-174. https://doi.org/10.1108/MD-04-2017-0296

Clemons, E. K., Gao, G., \& Hitt, L. M. (2006). When Online Reviews Meet Hyper Differentiation: A Study of the Craft Beer Industry. Journal of Management Information Systems, 23, 149-171. https://doi.org/10.2753/MIS0742-1222230207

Crawford, M. B. (2009). Shop Class as Soulcraft: An Inquiry into the Value of Work. New York: Penguin.

Elzinga, K. G., Tremblay, C. H., \& Tremblay, V. J. (2018). Craft Beer in the United States: Strategic Connections to Macro and European Brewers. In C. Garavaglia, \& J. Swinnen (Eds.), Economic Perspectives on Craft Beer. A Revolution in the Global Beer Industry (pp. 55-88). London: Palgrave Macmillan.

https://doi.org/10.1007/978-3-319-58235-1_2

European Network for SME Research (1997). The European Observatory for SMEs.

Fertő, I., Fogarasi, J., Major, A., \& Podruzsik, S. (2018). The Emergence and Survival of Microbreweries in Hungary. In C. Garavaglia, \& J. Swinnen (Eds.), Economic Perspectives on Craft Beer. A Revolution in the Global Beer Industry (pp. 211-228). London: Palgrave Macmillan. https://doi.org/10.1007/978-3-319-58235-1_8

Fillis, I. (2002). Creative Craft Behaviour in Britain and Ireland. Irish Marketing Review, $15,38-48$.

Garavaglia, C. (2020). The Emergence of Italian Craft Breweries and the Development of Their Local Identity. In N. Hoalst-Pullen, \& M. Patterson (Eds.), The Geography of Beer (pp. 135-147). Cham: Springer. https://doi.org/10.1007/978-3-030-41654-6_11

Garavaglia, C., \& Swinnen, J. (2018a). Economic Perspectives on Craft Beer. A Revolution in the Global Beer Industry. London: Palgrave Macmillan. 
https://doi.org/10.1007/978-3-319-58235-1

Garavaglia, C., \& Swinnen, J. (2018b). Economics of the Craft Beer Revolution: A Comparative International Perspective. In C. Garavaglia, \& J. Swinnen (Eds.), Economic Perspectives on Craft Beer. A Revolution in the Global Beer Industry (pp. 3-51). London: Palgrave Macmillan. https://doi.org/10.1007/978-3-319-58235-1

Garavaglia, C., \& Swinnen, J. (2020). Industry Concentration and the Entry of Craft Producers into the Global Beer Market. In E. S. Madsen, J. Gammelgaard, \& B. Hobdari (Eds.), New Developments in the Brewing Industry: The Role of Institutions and Ownership (pp. 216-234). Oxford: Oxford University Press.

Green, P. E., \& Krieger, A. M. (1991). Segmenting Markets with Conjoint Analysis. Journal of Marketing, 55, 20-31. https://doi.org/10.1177/002224299105500402

Green, P. E., \& Srinivasan, V. (1978). Conjoint Analysis in Consumer Research: Issues and Outlook. Journal of Consumer Research, 5, 103-123. https://doi.org/10.1086/208721

Green, P. E., \& Srinivasan, V. (1990). Conjoint Analysis in Marketing: New Developments with Implications for Research and Practice. Journal of Marketing, 54, 3-19. https://doi.org/10.1177/002224299005400402

Greenhalgh, P. (2003). The Persistence of Craft: The Applied Arts Today. New Brunswick: Rutgers University Press.

Henson, S. (1996). Consumer Willingness to Pay for Reductions in the Risk of Food Poisoning in the UK. Journal of Agricultural Economics, 47, 403-420. https://doi.org/10.1111/j.1477-9552.1996.tb00701.x

Hornaday, R. (1990). Dropping the e-Words from Small Business Research: An Alternative Typology. Journal of Small Business Management, 28, 22-33.

Inkson, K. (1987). The Craft Ideal and the Integration of Work: A Study of Potters. Human Relations, 40, 163-176. https://doi.org/10.1177/001872678704000304

Jakob, D. (2013). Crafting Your Way Out of the Recession? New Craft Entrepreneurs and the Global Economic Downturn. Cambridge Journal of Regions, Economy and Society, 6, 127-140. https://doi.org/10.1093/cjres/rss022

Johnson, M. W. (2009). Work We Can Believe In. Why Manual Work Is Making a Comeback. Financial Times, June 27-28.

Krystallis, A., \& Chryssohoidis, G. (2005). Consumers' Willingness to Pay for Organic Food: Factors That Affect It and Variation per Organic Product Type. British Food Journal, 107, 320-343. https://doi.org/10.1108/00070700510596901

Lancaster, K. J. (1966). A New Approach to Consumer Theory. Journal of Political Economy, 74, 132-157. https://doi.org/10.1086/259131

Lancaster, K. J. (1971). Modern Consumer Theory. Aldershot: Elgar.

Mariani, P., Marletta, A., \& Zenga, M. (2019). A New Relative Importance Index of Evaluation for Conjoint Analysis: Some Findings for CRM Assistant. Social Indicators Research, 146, 135-148. https://doi.org/10.1007/s11205-018-1980-6

Marques, C. S., Santos, G., Ratten, V., \& Barros, A. B. (2019). Innovation as a Booster of Rural Artisan Entrepreneurship: A Case Study of Black Pottery. International Journal of Entrepreneurial Behavior \& Research, 25, 753-772. https://doi.org/10.1108/IJEBR-02-2018-0104

Micelli, S. (2011). Futuro artigiano. L'innovazione nelle mani degli italiani. Venezia: Marsilio.

Pietrykowski, B. (2004). You Are What You Eat: The Social Economy of the Slow Food Movement. Review of Social Economy, 62, 307-321. 
https://doi.org/10.1080/0034676042000253927

Poettschacher, E. (2005). Strategic Creativity-How Values, Beliefs and Assumptions Drive Entrepreneurs in the Creative Industries. The International Journal of Entrepreneurship and Innovation, 6, 177-183. https://doi.org/10.5367/0000000054662809

Rao, V. R. (2014). Applied Conjoint Analysis. Berlin/Heidelberg: Springer-Verlag. https://doi.org/10.1007/978-3-540-87753-0

Ratten, V., \& Tajeddini, K. (2017). Innovativeness in Family Firms: An Internationalization Approach. Review of International Business and Strategy, 27, 217-230. https://doi.org/10.1108/RIBS-12-2016-0085

Sarstedt, M., Bengart, P., Shaltoni, A. M., \& Lehmann, S. (2018). The Use of Sampling Methods in Advertising Research: A Gap between Theory and Practice. International Journal of Advertising, 37, 650-663. https://doi.org/10.1080/02650487.2017.1348329

Sassatelli, R., \& Davolio, F. (2010). Consumption, Pleasure and Politics: Slow Food and the Politico-Aesthetic Problematization of Food. Journal of Consumer Culture, 10, 202-232. https://doi.org/10.1177/1469540510364591

Schnell, S. M. (2013). Deliberate Identities: Becoming Local in America in a Global Age. Journal of Cultural Geography, 30, 55-89. https://doi.org/10.1080/08873631.2012.745984

Schnell, S. M., \& Reese, J. F. (2003). Microbreweries as Tools of Local Identity. Journal of Cultural Geography, 21, 45-69. https://doi.org/10.1080/08873630309478266

Sennett, R. (2008). The Craftsman. New Haven/London: Yale University Press.

Walley, K., Parsons, S., \& Bland, M. (1999). Quality Assurance and the Consumer: A Conjoint Study. British Food Journal, 101, 148-162.

https://doi.org/10.1108/00070709910261936 